\title{
Relationship between Teacher Views on Levels of Organizational Support - Organizational Identification and Climate of Initiative
}

\author{
Şenay Sezgin Nartgün ${ }^{1, *}$, Sevgi Taşkın ${ }^{2}$ \\ ${ }^{1}$ Department of Educational Sciences, Faculty of Education, Abant Izzet Baysal University, Turkey \\ ${ }^{2}$ Minister of National Education, Turkey
}

Copyright $\bigcirc 2017$ by authors, all rights reserved. Authors agree that this article remains permanently open access under the terms of the Creative Commons Attribution License 4.0 International License

\begin{abstract}
This study aimed to identify secondary school teachers' views on levels of organizational support, organizational identification and climate of initiative and to determine whether there were any significant differences between these views based on teachers' demographic characteristics and whether there were significant differences between teachers' climate of initiative levels and levels of their organizational support and organizational identification. Universe of the study conducted with relational screening model was composed of teachers $(n=240)$ employed in Bolu province Anatolian High Schools during 2014-2015 academic year. Organizational Support, Organizational Identification and Climate of Initiative Scales were used in the study as data collection tools. According to research results, teachers were "undecided" in their organizational identification and climate of initiative levels, "agreed" with the organizational support level total scale and its instructional support and justice support sub dimensions and "partially" agreed with the administrative support dimension. While there were no significant differences in teacher views on climate of initiative, organizational support and all its sub dimensions based on gender, marital status, level of education, professional seniority, age and union membership variables, significant differences were identified on organizational identification levels based on age and level of education variables. A low level, positive meaningful relationship was identified for teachers' climate of initiative, organizational identification and total support, support administrative and support justice levels which are organizational support sub dimensions and no significant relationships were detected with instructional support levels.
\end{abstract}

Keywords Organizational Support, Organizational Identification, Climate of Initiative, Teacher

\section{Introduction}

Teachers' roles and responsibilities in today's system of education are increasing day by day in the process and schools as institutions, students and parents expect teachers to display high performance in performing these duties. As individuals, teachers are having a hard time in the face of these escalating roles. In order to transform these responsibilities to achievements, teachers expect support from their organizations and their administrators at a level that can meet their needs and expectations, that can provide opportunities for professional development in academic terms and that can create a peaceful and happy work environment which will ensure that teachers are valued and paid attention to. Teachers' organizational support perceptions related to their organizations and creation of organizational identification and climate of initiative levels are regarded as important concepts for organizational achievement and its future performance and the degree how much these concepts are taken into consideration in providing teachers with positive work climate in their organizations is investigated. Hence, existence of teachers, one of the most important elements of education system, who are aware of the support they can receive dominantly from school administration, parents and the school environment, who are motivated to provide active and successful education by identifying themselves with their organizations, who exert efforts to be more effective in line with the goals of their organizations and who contribute to the increase in the quality of education and training by taking more initiatives is crucial to target a successful future in the field of education both for educational organizations and for the country.

\subsection{Organizational Support}

Teachers are the building blocks of the training and education process and their attitudes towards school and the 
development of their sense of belonging to school via integration positively affect their performances. In addition, school administrators' positive approaches to teachers, having teachers participate in decisions made in schools and giving teachers support and responsibility highly affect teachers' job satisfaction and organizational commitment and play a significant role in this sense to increase the quality and effectiveness of education and training [33]. Teachers develop a positive attitude towards their schools when they are provided with a suitable work climate and when they feel they are supported by the school administration. Therefore, the concept of "organizational support" is at the forefront in creating positive perceptions in teachers towards their organizations. The concept of organizational support is employees' belief that the members of the organization value them and care for their wellbeing [31], the awareness of an organization about the contributions of employees and its caring for the well-being of employees [66] and the level of perception related to organizational commitment of the organization towards its employees that develops in time in employees via their integration with their organizations [17]. The concept of organizational support is defined as employees' awareness that the organization supports them and recognizes their contributions, meets the employees' needs for belonging, respect and validation by making them feel that the organization cares for their well-being and it is happy to be working with them [6], as employees' reciprocation of high level of commitment and performance towards organizational activities that are deemed to be useful for them [80] and as employees' positive perceptions towards contributions, approval, feelings and information from various sources [77]. When employees know that their ideas are noticed and their criticisms are taken into consideration to influence changes in the organization, they will receive it as support and their performance will increase along with their sense of belonging to the organization [70]. In school environments, administrators need to be influential on teachers to realize organizational goals by increasing teachers' commitment and meeting their needs $[48 ; 73]$. Meeting the needs of employees, noticing their contributions and looking after their interests will result in positive reciprocations for the organization [71]. Value given to employees by the organization is a sign that employees are recognized and approved [23]. On the other hand, in work environments where organizational support is not sufficiently perceived, mutual trust and sharing are nonexistent between the individual and the organization, employees feel unvalued and that situation is negatively reflected on their performances [90]. With the help of shared cultural elements and received organizational support, members of a school are integrated with the school and its goals and contribute to the development of humanitarian feelings such as friendship, sincerity, trust and ensure the formation of we-feeling instead of promoting the sense of self [92]. With the help of support received from their organization, teachers in the school environment are engaged in activities that are useful for their organizations such as making suggestions to improve their climate, participating in meetings willingly, approaching their colleagues positively and helping them in their work [71]. It is observed that when teachers perceive organizational support positively, they spend time together and increase the trust and affinity among them. This generates the social climate that is sought in the organization and communication is ongoing with the programs and social activities they arrange among themselves. In this context, teachers are take pride in and feel happy from the organizational support they receive and their level of welfare [2] and they will adopt behaviours that will be approved by the organization and that will benefit their organizations since they will identify their goals and the goals of the organization.

\subsection{Organizational Identification}

Meeting the needs of teachers by educational organizations is associated with the climate and culture of the organization in question. Schools have specific expectations from teachers such as having skills like expressing oneself, being creative and being able to work in a team. In order for teachers to meet these expectations, the academic expression, climate and atmosphere that the school offers are significant. Hence, it is imperative to realize that the schools should provide the crucial conditions for teachers to do their duties and understand the factors that inhibit teachers from doing so. Educational administrators and the organizational climate should affect teachers, ensure that teachers participate in the service and therefore increase their productivity. Educational organizations have to meet teachers' economic, physical, social and psychological needs in order to reach their goals. Teachers who felt approved, liked and respected in the organization become happy and productive by knowing that they have reached this level as a result of the services they provide. Hence, teachers identify with their profession by keeping their morale high via sense of achievement [86]. Increases in organizational identification results in the increase of acting and thinking from an organizational perspective [29]. Organizational identification is defined as the cognitive connection between the individual and the organization [29]. The general understanding about organizational identification is that it is generated when individuals feel as a part of the organization and form psychological ties with the organization $[18 ; 97]$ in the framework of cognitive, affective and behavioral factors [95]. Affective commitment of employees that identify with their organizations and high level of overlap between employees' needs and thoughts with those of organizational goals [26] become meaningful for them and therefore provide more positive motivation to increase their desire to keep working at the organization. In this scenario, the possibility of favoritism lessens and employees are directed on their own 
to behaviors that support their organization and exert efforts for the benefit of their organizations voluntarily [49]. Identification provides the opportunity for employees to realize organizational goals and activities by individually adapting to organizational goals and values. Also, individuals remove any uncertainty by accepting organizational objectives and values. When interacting with outsiders, individuals who identify with their organizations highlight the interests of the organization at times related to strategic and business decisions by regarding themselves as the representatives of their organization, on the other hand, administrators of the organization avoid people who are against the values and goals of the organization [61]. Full identification of individuals with their organizations by completely adopting mutual beliefs, attitudes, values and goals, i.e. high levels of organizational identification, means that the individual will defend the organization in various platforms by voluntarily giving all kinds of support and will exert any efforts to ensure that the organizations reach its goals. As a result of such behaviors that will be presented by individuals, it is expected that productivity and performance will increase in the organization, the costs will decrease, high level coordination and cooperation will be ensured and the organization will adapt to environmental changes more easily, which means that organizational performance is expected to increase in almost all domains [34]. As a result, studies in the field reported that organizational identification increased organizational performance positively and developed organizational integrity since it provided feelings of happiness in employees [81].

\subsection{Climate of Initiative}

It is observed that employee performance increases in work climates where employees take the initiative and their creativity is supported by their organizations [84]. Teachers who are in a sharing position with their organizations and who can take the initiative when necessary have positive thoughts towards their organizations and aim to take responsibility in increasing the achievements of the organization by working in harmony with their colleagues. Hence, this positive climate provided by the organization with their employees plays an important role in increasing performance for both teachers and the organization. The organization will act as the locomotive to ensure that the individual and organizational goals are reached by putting the mutual decisions made by school administration and teachers into practice and by ensuring synergy. Climate of initiative can be expressed as teachers' overcoming the barriers they faced by displaying behaviors for the benefit of the organization. As a result of the positive work climate formed between the organization and the individual, the individual goes beyond the formal roles required by the task and presents adamant behaviors to accomplish the task and completes the process successfully [39; 40]. It is also observed that performance increases in work climates where individuals take the initiative in organizations and their work is supported [84]. Having organizational climate at the desired level is a significant concept in organizational achievement for both theoretical and practical reasons [39]. Taking the initiative is the act of completing tasks for the benefit of the organization without guidance from an administrator [89]. Initiative is characterized as the quality of individuals who can focus on goals to be achieved and take risks for the organization when required [39]. Climate of initiative is related to individuals' taking responsibility in the organization [63]. Individuals' taking responsibility in the organization, feeling responsible towards their organization, keeping personal interests in the background in actions are important in the concept of initiative as well as the feelings of impartiality evoked by the administration in individuals who benefit the organization [63]. Climate of initiative is the display of active roles voluntarily by individuals to reach desired goals or remove obstacles [38; 40]. Climate of initiative is the tendency of employees in job environments to display more decisive behaviors [45]. Climate of initiative is defined as the work behavior in the quest of a goal that arises on its own to remove obstacles [39]. Climate of initiative can be regarded as another form of employees' proactive behavior directed for a permanent goal focusing on the task at hand [68]. It is defined as employees' taking the initiative to develop or form new conditions [13]. It is determined that employees with various behaviors and tendencies display a different attitude by taking the initiative after identifying a common goal for the organization [13]. These types of behaviors aim to develop individuals' personal prerequisites in addition to developing specified work methods and procedures in order to foresee the future [88]. Climate of initiative is the activation of personal responsibilities for employees to increase their performances actively [38]. The concept is also explained as expansion employees' concept of performance and taking on the initiative for various extra role performances in changing job conditions [40]. Individuals who take personal initiatives go beyond their responsibilities and aim to overcome obstacles in reaching their goals with self-initiation and active approach. It is observed that these individuals have high academic achievement and self- confidence [104]. Individuals who are engaged in sharing with their organization and who can take the initiative inside the organization when necessary maintain positive feelings towards their organizations and aim to take responsibility by working in harmony with other employees to increase the success of the organization. Therefore, this positive climate obtained by the organization plays an important role in increasing performance in both the organization and in employees. The organization will act as the locomotive to ensure that the individual and organizational goals are reached by putting the mutual decisions made by the administration and individual into practice and by ensuring 
synergy.

\subsection{Relationship of Organizational Support, Organizational Identification and Climate of Initiative}

Individuals need to receive support from their organizations. With organizational support, individuals meet their affective needs such as being respected, approved and recognized and valued. With the support it provides, the organization states that it is aware of employees' performances, it cares for their wellbeing and it is satisfied working with them in line with organizational goals and meets vital employee needs such as respect and approval of colleagues and administrators in the organization that are crucial for organizational success [71]. Individuals appreciate the support given to them and their colleagues by the organization and exert efforts to identify more with their organization. The individuals who identify with their organization increase their performance without experiencing any problems by taking short and long term goals and values of the organization into consideration and try to introduce the obtained achievements as the success of the organization without thinking of them as personal achievements. Teachers' identification with their schools will primarily increase communication among colleagues, feelings of acting together and responsibility for and commitment to their organization as well as moving the efficiency and effectiveness of the organization to higher levels. When teachers act to increase the level of achievement in their organization by identifying themselves with the organization with the support they receive from their schools, they face with many challenges. Faced by these problems, teachers prevent the organization from negative impacts and deviating from specified goals by taking personal initiatives. Teachers make plans using foresight to save the organization from unexpected negative conditions and try to overcome problems. However, teachers have better performances when administrators appreciate these behaviors and value their suggestions and act as a locomotive for organizational success by not abstaining from going one step further. Especially in recent years, teachers have faced many innovations that have abruptly developed during the education and training process and they devote themselves to ensure the quality of the organization and education do not fall behind in the process. However, in order for teachers to continue these self-abnegating behaviors, they need to receive physical and technical support from school administration and they need a positive organizational climate in which they can identify with the school and take initiative. It is also believed that teachers who identify with their organizations and who are fairly supported by school administrations in the education and training process will take on more responsibility and initiative in the realization of short and long term goals of the country.

Literature review shows organizational support has been investigated in terms of organizational commitment $[79 ; 15$; $73 ; 82 ; 1 ; 109 ; 42 ; 70 ; 99 ; 57 ; 100 ; 67 ; 22 ; 21 ; 51]$, intention to leave $[79 ; 74 ; 107 ; 17]$, identification $[72 ; 97 ; 36 ; 78 ; 65$; 46], organizational citizenship [85], organizational commitment [14], loneliness [54], trust [7; 91; 35; 44; 30] and burn out $[7 ; 47 ; 69]$. Organizational identification has been studied together with job satisfaction $[56 ; 20]$, organizational image and citizenship $[52 ; 53 ; 64 ; 93 ; 106]$, organizational trust $[98 ; 24 ; 94 ; 108 ; 101]$ and intention to leave $[16 ; 76 ; 96 ; 87]$. It is observed that climate of initiative is a new field in literature and has been studied with concepts such as organizational support and trust [59] and creativity [11]. In the light of this information, no study that has investigated organizational support, identification and initiative levels together was found both in national or international level. Hence this study is significant for contributing to the field in this sense.

This study is significant to provide teachers with a new perspective to teaching profession with the support they receive from their organizations, to create new research fields related to organizational support, identification and taking initiative levels for administrators and teachers in educational institutions and provide suggestions which can be implemented. It is believed that organizational support provided by the organization for its employees will prove to be beneficial when it is sufficient and honest and it will be possible to evaluate these acquisitions. Organizational support provided for teachers is believed to increase their interest and commitment to the organization as long as they work in the organization and it will be instrumental in realizing organizational goals.

In this context, this study aimed to identify teacher views on levels of organizational support, organizational identification and climate of initiative and to determine whether these views significantly differed based on demographic variables. Answers to questions provided below were sought with this aim in mind.

1. What are teacher views on the levels of organizational support, organizational identification and climate of initiative?

2. Do teacher views on the levels of organizational support, organizational identification and climate of initiative significantly differ based on independent variables (gender, marital status, professional seniority, level of education, union membership)?

3. Is there a meaningful relationship between teacher views on climate of initiative and levels of organizational support and organizational identification?

\section{Method}

\subsection{Research Method}

This quantitative study employed relational screening 
model to investigate whether high school teachers' views on the levels of organizational support, organizational identification and climate of initiative differed based on different variables. Relational screening model is defined as a research model that aims to identify the existence and/or degree of change between two or more variables. Relational analysis is done by using correlation type relations or comparisons in relational screening models [12; 55]

\subsection{Study Universe}

The universe of the study was composed of teachers employed in six Anatolian High Schools (expect for science high school and vocational technical schools) in Bolu central district during 2014-2015 academic year. The reason for selection of these high schools is structural similarity. A total of 217 teachers were distributed the data collection tool to make sure all the universe was contacted and 240 of these tools were assessed. Accordingly, return rate was calculated as $92,25 \%$. Based on Krejcie and Morgan [58], this return rate is sufficient to represent the universe.

Examination of the personal information shows that 136 of the participating teachers were $(56,7 \%)$ female, 104 were $(43,3 \%)$ male; 190 were $(79,1 \%)$ married, 51 were $(20,9 \%)$ single; 193 were undergraduate $(80,1 \%), 47$ were $(18,9 \%)$ post graduate; 175 had $(72,6 \%)$ union membership and 65 did not have $(26,6 \%)$ any union membership. Also, 74 of the participating teachers $(30,8 \%)$ had $0-10$ years seniority, 53 had(22,1\%) 11-15 years seniority; 58 had (24,2\%) 16-20 years seniority; 29 had $(12,1 \%) 21-25$ years seniority and 26 had $(10,8 \%) 26$ years or more seniority.

\subsection{Data Collection Tools}

A question form with four sections was used in the study as data collection tool. The first section includes demographic variables. The other two sections include Organizational Support Scale to measure the degree of support employees receive in the organization and Organizational Identification Scale to measure teachers' organizational identification and the last section includes Climate of Initiative Scale to determine the level of initiative taking in the organization by employees. Personal information form included questions to determine information thought to be relevant to research results such as gender, age, marital status, union membership, professional seniority and level of education.

Organizational Support Scale was developed by Derinbay [27] and it consists of 29 items. The reliability Cronbach Alpha internal consistency coefficient was established as, 95 . The three sub dimensions for Organizational Support Scale are as follows: instructional support (items 1-9), administrative support (items 10-18), and justice support (items 19-29). In this study, Cronbach Alpha internal consistency coefficient was calculated as $\alpha: 92$ with values for sub dimensions changing between,73 and ,93.
Organizational Identification Scale has 11 items and the scale was translated to Turkish by Loga [60] using the first 8 items from the study of Fred Mael and the remaining 3 items from the studies of Massimo Bergami and Richard P. Bagozzi. The scale is one-dimensional. Reliability and construct validity of the scale was established by Loga [60] and Cronbach Alpha internal consistency coefficient of the scale was found to be, 87.,84. Climate of Initiative Scale was translated into Turkish by Kurt, Duyar and Yakut [59] by utilizing the studies by Frese, Fay, Hilburger, Leng and Tag [40]. Climate of Initiative Scale consists of 7 items and it is a 5 point Likert type scale. Cronbach Alpha internal consistency coefficient of Climate of Initiative Scale was calculated as, 87. In this study, Cronbach Alpha internal consistency coefficient of the scale was calculated as, 92 .

\subsection{Data Collection}

Required permits were received from Bolu National Directorate of Education for the study. Data collection tool was personally distributed by the researcher by visiting the 6 high schools located in the central distinct. The schools were revisited to collect the completed scales and they were personally collected by the assistance of school administrators and teachers. Data collection tool was distributed to all teachers at 6 schools and voluntary nature of participation was emphasized.

\subsection{Data Analysis}

Before data analysis, Kolmogorov-Smirnov Normality Test was conducted to determine whether data displayed normal distribution and it was observed that data did not show normal distribution. Hence, non-parametric tests were used in data analysis. Frequencies (f) and percentage (\%) values were calculated for personal information. Means ( $\bar{X})$ and standard deviation (SD) values -descriptive statisticswere used for teachers' organizational support, organizational identification and climate of initiative levels. Kruskal Wallis and Mann Whitney U tests were utilized to compare teacher views based on independent variables. Spearman's Rank Correlation Coefficient was utilized to determine whether there were relationships between obtained views. Score intervals used in data analysis for teachers' data in organizational support, organizational identification and climate of initiative scales were as follows; 1,00-1,79 Completely disagree, 1,80-2,59 Disagree, 2,603,39 Undecided, 3,40-4,19 Agree and 4,20-5,00 Completely agree.

\section{Findings and Discussion}

This section includes findings and interpretations related to data analysis for the research problem in terms of sub problems. 


\subsection{Teacher Views on the Level of Organizational Support, Organizational Identification and Climate of Initiative}

Data pertaining to teacher views on the first sub problem of the relationship between teachers' organizational support and organizational identification levels and climate of initiative were presented in Table 3 as arithmetic means and standard deviation values.

Table 1. Results of descriptive statistics for the relation between levels of teachers' organizational support and organizational identification and climate of initiative

\begin{tabular}{|c|c|c|c|c|}
\hline Scale & Sub Dimension & $\mathrm{N}$ & $\overline{\mathrm{X}}$ & $\mathrm{SD}$ \\
\hline \multicolumn{2}{|c|}{ Identification } & 240 & 3,36 &, 67 \\
\hline \multicolumn{2}{|c|}{ Climate of Initiative } & 240 & 3,09 &, 28 \\
\hline \multirow{2}{*}{ Organizational } & Instructional support & 240 & 3,40 &, 54 \\
support & Administrative & 240 & 3,24 &, 42 \\
& support & 240 & 3,45 &, 71 \\
& Justice support & 240 & 3,49 &, 72 \\
\hline
\end{tabular}

Table 1 shows that teachers were "undecided" about their organizational identification levels with $(\bar{X}=3,36)$ means. Based on this finding, it is believed that this situation is related to differences in working hours in addition to factors such as sense of belonging to their schools, climate, administrator and colleagues. Teacher views on their organizational support levels shows "agreement" on the sub dimensions of organizational support: justice support
( $\bar{X}=3,50)$, instructional support ( $\bar{X}=3,40)$ and total support ( $\bar{X}=3,49$ ) but it was found to be "partial" agreement on administrative support $(\bar{X}=3,09)$. It is observed that teachers were "undecided" about climate of initiative levels $(\bar{X}=3,09)$.

\subsection{Teacher Views Based on Personal Variables}

\subsubsection{Gender Variable}

Results of Mann Whitney U test conducted to identify the relationship between teachers' levels of organizational support and organizational identification and climate of initiative based on gender are presented in Table 3-2.

Table 2 shows no significant differences in teacher views based on gender in organizational identification $(U=6501,50$; $p>0.05)$, climate of initiative $(U=6632,00 ; p>0.05)$ and organizational support total $(U=6931,50 ; p>0.05)$ and the sub dimensions instructional support ( $U=6761,50 ; p>0.05$ ), administrative support $(\mathrm{U}=7041,00 ; \mathrm{p}>0.05)$ and justice support $(U=6921,50 ; p>0.05)$.

\subsection{Marital Status Variable}

Table 3 provides the results of the tests conducted to identify the relationship between teachers' levels of organizational support and organizational identification and climate of initiative based on marital status.

Table 2. Mann Whitney U test results for the relationship between teachers' levels of organizational support and organizational identification and climate of initiative based on gender.

\begin{tabular}{|c|c|c|c|c|c|c|}
\hline Scale & Sub Dimension & Sex & $\mathrm{N}$ & Mean Rank & $\mathrm{U}$ & $p$ \\
\hline \multicolumn{2}{|c|}{ Identification } & $\begin{array}{l}\text { Female } \\
\text { Male }\end{array}$ & $\begin{array}{l}136 \\
104\end{array}$ & $\begin{array}{l}116,31 \\
125,99\end{array}$ & 6501,50 &, 28 \\
\hline \multicolumn{2}{|c|}{ Climate of Initiative } & $\begin{array}{c}\text { Female } \\
\text { Male }\end{array}$ & $\begin{array}{l}136 \\
104\end{array}$ & $\begin{array}{l}117,26 \\
124,73\end{array}$ & 6632,00 &, 40 \\
\hline \multirow{4}{*}{$\begin{array}{l}\text { Organizational } \\
\text { support }\end{array}$} & Instructional Support & $\begin{array}{l}\text { Female } \\
\text { Male }\end{array}$ & $\begin{array}{l}136 \\
104\end{array}$ & $\begin{array}{l}118,09 \\
122,49 \\
\end{array}$ & 6761,50 & ,62 \\
\hline & Administrative Support & $\begin{array}{l}\text { Female } \\
\text { Male }\end{array}$ & $\begin{array}{l}136 \\
104 \\
\end{array}$ & $\begin{array}{l}120,73 \\
120,20 \\
\end{array}$ & 7041,00 & ,95 \\
\hline & Justice Support & $\begin{array}{c}\text { Female } \\
\text { Male }\end{array}$ & $\begin{array}{l}136 \\
104\end{array}$ & $\begin{array}{l}119,39 \\
121,95\end{array}$ & 6921,50 &, 77 \\
\hline & Total & $\begin{array}{c}\text { Female } \\
\text { Male }\end{array}$ & $\begin{array}{l}136 \\
104\end{array}$ & $\begin{array}{l}119,34 \\
120,85\end{array}$ & 6931,50 &, 86 \\
\hline
\end{tabular}

Table 3. Mann Whitney U test results for the relationship between teachers' levels of organizational support and organizational identification and climate of initiative based on marital status.

\begin{tabular}{|c|c|c|c|c|c|c|}
\hline Scale & Sub Dimension & Marital Status & $\mathrm{N}$ & Mean Rank & $\mathrm{U}$ & $p$ \\
\hline \multicolumn{2}{|c|}{ Identification } & $\begin{array}{l}\text { Married } \\
\text { Single }\end{array}$ & $\begin{array}{c}189 \\
50 \\
\end{array}$ & $\begin{array}{c}126,95 \\
93,73\end{array}$ & 3,74 & ,44 \\
\hline \multicolumn{2}{|c|}{ Climate of Initiative } & $\begin{array}{l}\text { Married } \\
\text { Single }\end{array}$ & $\begin{array}{c}189 \\
50 \\
\end{array}$ & $\begin{array}{l}121,52 \\
114,25 \\
\end{array}$ & 1,58 &, 81 \\
\hline \multirow{4}{*}{$\begin{array}{l}\text { Organizational } \\
\text { support }\end{array}$} & Instructional Support & $\begin{array}{l}\text { Married } \\
\text { Single }\end{array}$ & $\begin{array}{c}189 \\
50\end{array}$ & $\begin{array}{l}118,06 \\
124,93\end{array}$ & 1,45 &, 83 \\
\hline & Administrative Support & $\begin{array}{l}\text { Married } \\
\text { Single }\end{array}$ & $\begin{array}{c}189 \\
50 \\
\end{array}$ & $\begin{array}{l}117,54 \\
129,28\end{array}$ & 5,91 & ,20 \\
\hline & Justice Support & $\begin{array}{l}\text { Married } \\
\text { Single }\end{array}$ & $\begin{array}{c}189 \\
50 \\
\end{array}$ & $\begin{array}{l}119,53 \\
121,76 \\
\end{array}$ & 5,01 & ,28 \\
\hline & Total & $\begin{array}{l}\text { Married } \\
\text { Single }\end{array}$ & $\begin{array}{c}189 \\
50\end{array}$ & $\begin{array}{l}117,68 \\
126,34\end{array}$ & 5,31 & ,25 \\
\hline
\end{tabular}


Table 3 shows no significant differences in organizational identification $(U=3,74 ; p>0.05)$, climate of initiative $(\mathrm{U}=1,58 ; \mathrm{p}>0.05)$, total organizational support $(\mathrm{U}=5,31$; $\mathrm{p}>0.05$ ) and sub dimensions instructional support $(U=1,45$; $\mathrm{p}>0.05)$, administrative support $(\mathrm{U}=5,91 ; \mathrm{p}>0.05)$ and justice support $(\mathrm{U}=5,01 ; \mathrm{p}>0.05)$ based on marital status variable. It can be argued that lack of a significant difference means marital status is not an effective variable on teacher views.

\subsection{Level of Education Variable}

Table 4 provides the test results conducted to identify the relationship between teachers' levels of organizational support and organizational identification and climate of initiative based on level of education variable.
Table 4 displays no significant differences in teachers views on climate of initiative ( $U=4367,00 ; p>0.05)$, and organizational support sub dimensions: instructional support $(\mathrm{U}=4026,50 ; \mathrm{p}>0.05), \quad$ administrative support $(U=4437,00 ; p>0.05)$, justice support $(U=4451,50 ; p>0.05)$ and total organizational support $(U=4441,50 ; p>0.05)$ based on level of education. Lack of a significant difference in this regard may mean that level of education variable is does not affect teacher views. On the other hand, a significant difference was detected in the level of organizational identification $(U=3360,50 ; p<0.05)$ based on level of education between teachers with undergraduate training and post graduate training in favor of teachers with undergraduate training.

Table 4. Mann Whitney U test results for the relationship between teachers' levels of organizational support and organizational identification and climate of initiative based on level of education.

\begin{tabular}{|c|c|c|c|c|c|c|}
\hline Scale & Sub Dimension & Level of education & $\mathbf{N}$ & Mean Rank & $\mathbf{U}$ & $p$ \\
\hline \multicolumn{2}{|c|}{ Identification } & $\begin{array}{l}\text { Undergraduate } \\
\text { Post graduate }\end{array}$ & $\begin{array}{c}193 \\
47\end{array}$ & $\begin{array}{c}126,59 \\
95,50\end{array}$ & 3360,50 &, $00 *$ \\
\hline \multicolumn{2}{|c|}{ Climate of Initiative } & $\begin{array}{l}\text { Undergraduate } \\
\text { Post graduate }\end{array}$ & $\begin{array}{c}193 \\
47\end{array}$ & $\begin{array}{l}119,63 \\
124,09 \\
\end{array}$ & 4367,00 & ,69 \\
\hline \multirow{4}{*}{$\begin{array}{l}\text { Organizational } \\
\text { support }\end{array}$} & Instructional Support & $\begin{array}{l}\text { Undergraduate } \\
\text { Post graduate }\end{array}$ & $\begin{array}{c}193 \\
47\end{array}$ & $\begin{array}{l}117,47 \\
130,33 \\
\end{array}$ & 4026,50 &, 25 \\
\hline & Administrative Support & $\begin{array}{l}\text { Undergraduate } \\
\text { Post graduate }\end{array}$ & $\begin{array}{c}193 \\
47\end{array}$ & $\begin{array}{l}119,99 \\
122,60\end{array}$ & 4437,00 &, 81 \\
\hline & Justice Support & $\begin{array}{l}\text { Undergraduate } \\
\text { Post graduate }\end{array}$ & $\begin{array}{c}193 \\
47\end{array}$ & $\begin{array}{l}120,94 \\
118,71\end{array}$ & 4451,50 & ,84 \\
\hline & Total & $\begin{array}{l}\text { Undergraduate } \\
\text { Post graduate }\end{array}$ & $\begin{array}{c}193 \\
47\end{array}$ & $\begin{array}{l}119,63 \\
121,50\end{array}$ & 4441,50 &, 86 \\
\hline
\end{tabular}

Table 5. Kruskal Wallis test results for the relationship between teachers' levels of organizational support and organizational identification and climate of initiative based on professional seniority

\begin{tabular}{|c|c|c|c|c|c|c|c|c|}
\hline & Sub Dimension & $\begin{array}{c}\text { Professional } \\
\text { Seniority }\end{array}$ & $\mathrm{N}$ & Mean Rank & df & $\times 2$ & $\mathrm{p}$ & $\begin{array}{l}\text { Significant } \\
\text { differences }\end{array}$ \\
\hline \multicolumn{2}{|c|}{ Identification } & $\begin{array}{c}0-10 \\
11-15 \\
16-20 \\
21-25 \\
26-+\end{array}$ & $\begin{array}{l}74 \\
53 \\
58 \\
29 \\
26\end{array}$ & $\begin{array}{l}113,89 \\
111,82 \\
125,71 \\
137,34 \\
126,60\end{array}$ & 4 & 3,74 & ,44 & -- \\
\hline \multicolumn{2}{|c|}{ Climate of Initiative } & $\begin{array}{c}0-10 \\
11-15 \\
16-20 \\
21-25 \\
26-+ \\
\end{array}$ & $\begin{array}{l}74 \\
53 \\
58 \\
29 \\
26\end{array}$ & $\begin{array}{l}128,32 \\
118,71 \\
115,65 \\
120,07 \\
113,21 \\
\end{array}$ & 4 & 1,58 &, 81 & -- \\
\hline \multirow{4}{*}{$\begin{array}{l}\text { Organizational } \\
\text { support }\end{array}$} & Instructional Support & $\begin{array}{c}0-10 \\
11-15 \\
16-20 \\
21-25 \\
26-+\end{array}$ & $\begin{array}{l}74 \\
53 \\
58 \\
29 \\
26\end{array}$ & $\begin{array}{l}114,82 \\
128,99 \\
117,96 \\
122,86 \\
117,69\end{array}$ & 4 & 1,45 &, 83 & -- \\
\hline & Administrative Support & $\begin{array}{c}0-10 \\
11-15 \\
16-20 \\
21-25 \\
26-+ \\
\end{array}$ & $\begin{array}{l}74 \\
53 \\
58 \\
29 \\
26\end{array}$ & $\begin{array}{l}107,77 \\
120,40 \\
137,04 \\
117,38 \\
123,52 \\
\end{array}$ & 4 & 5,91 & ,20 & -- \\
\hline & Justice Support & $\begin{array}{c}0-10 \\
11-15 \\
16-20 \\
21-25 \\
26-+ \\
\end{array}$ & $\begin{array}{l}74 \\
53 \\
58 \\
29 \\
26\end{array}$ & $\begin{array}{l}106,98 \\
123,58 \\
133,53 \\
120,81 \\
123,29 \\
\end{array}$ & 4 & 5,01 &, 28 & -- \\
\hline & Total & $\begin{array}{c}0-10 \\
11-15 \\
16-20 \\
21-25 \\
26-+\end{array}$ & $\begin{array}{l}74 \\
53 \\
58 \\
29 \\
26\end{array}$ & $\begin{array}{l}106,08 \\
122,88 \\
133,48 \\
121,22 \\
122,83\end{array}$ & 4 & 5,31 &, 25 & -- \\
\hline
\end{tabular}


Table 6. Mann Whitney U test results for the relationship between teachers' levels of organizational support and organizational identification and climate of initiative based on union membership.

\begin{tabular}{|c|c|c|c|c|c|c|}
\hline Scale & Sub Dimension & Union Membership & $\mathrm{N}$ & Mean Rank & $\mathrm{U}$ & $p$ \\
\hline \multicolumn{2}{|c|}{ Identification } & $\begin{array}{l}\text { Yes } \\
\text { No }\end{array}$ & $\begin{array}{c}175 \\
65 \\
\end{array}$ & $\begin{array}{l}123,01 \\
113,73 \\
\end{array}$ & 5247,50 &, 35 \\
\hline \multicolumn{2}{|c|}{ Climate of Initiative } & $\begin{array}{l}\text { Yes } \\
\text { No }\end{array}$ & $\begin{array}{c}175 \\
65 \\
\end{array}$ & $\begin{array}{l}119,33 \\
123,65 \\
\end{array}$ & 5483,00 & ,66 \\
\hline \multirow{4}{*}{$\begin{array}{l}\text { Organizational } \\
\text { support }\end{array}$} & Instructional Support & $\begin{array}{l}\text { Yes } \\
\text { No }\end{array}$ & $\begin{array}{c}175 \\
65 \\
\end{array}$ & $\begin{array}{l}123,36 \\
111,01 \\
\end{array}$ & 5070,50 &, 21 \\
\hline & Administrative Support & $\begin{array}{l}\text { Yes } \\
\text { No }\end{array}$ & $\begin{array}{c}175 \\
65 \\
\end{array}$ & $\begin{array}{l}123,53 \\
112,35\end{array}$ & 5158,00 & ,26 \\
\hline & Justice Support & $\begin{array}{l}\text { Yes } \\
\text { No }\end{array}$ & $\begin{array}{c}175 \\
65 \\
\end{array}$ & $\begin{array}{l}124,82 \\
108,87 \\
\end{array}$ & 4931,50 &, 11 \\
\hline & Total & $\begin{array}{l}\text { Yes } \\
\text { No }\end{array}$ & $\begin{array}{c}175 \\
65 \\
\end{array}$ & $\begin{array}{l}123,78 \\
109,87 \\
\end{array}$ & 4996,50 & ,16 \\
\hline
\end{tabular}

Table 7. Table of Correlation Analysis for teachers' climate of initiative and levels of organizational support and organizational identification

\begin{tabular}{|c|c|c|c|c|c|c|}
\hline & & Identification & $\begin{array}{c}\text { Organizational support } \\
\text { Total }\end{array}$ & $\begin{array}{c}\text { Instructional } \\
\text { Support }\end{array}$ & $\begin{array}{l}\text { Administrative } \\
\text { Support }\end{array}$ & $\begin{array}{l}\text { Justice } \\
\text { Support }\end{array}$ \\
\hline \multirow{3}{*}{$\begin{array}{l}\text { Climate of } \\
\text { Initiative }\end{array}$} & $\mathrm{r}$ &, $17^{*}$ &, $27 * *$ &, 01 &, $29 * *$ &, $28 * *$ \\
\hline & $\mathrm{p}$ &, 01 &, 00 & ,92 &, 00 & ,00 \\
\hline & $\mathrm{N}$ & 240 & 240 & 240 & 240 & 240 \\
\hline
\end{tabular}

\subsection{Professional Seniority Variable}

Table 5 provides the test results conducted to identify the relationship between teachers' levels of organizational support and organizational identification and climate of initiative based on professional seniority variable.

Table 5 shows no significant differences in teacher views on organizational identification $\left[\mathrm{X}^{2}(\mathrm{sd}=2 . \mathrm{n}=371)=3,74\right.$; $\mathrm{p}>0.05]$, climate of initiative $\left[\mathrm{X}^{2}(\mathrm{sd}=2 . \mathrm{n}=371)=1,58\right.$; $\mathrm{p}>0.05]$, total organizational support $\left[\mathrm{X}^{2}(\mathrm{sd}=2 . \mathrm{n}=371)=5,31\right.$; $\mathrm{p}>0.05$ ] and sub dimensions of organizational support; instructional support $\left[\mathrm{X}^{2}(\mathrm{sd}=2 . \mathrm{n}=371)=1,45 ; \mathrm{p}>0.05\right]$, administrative support $\left[X^{2}(s d=2 . n=371)=5,91 ; p>0.05\right]$ and justice support $\left[\mathrm{X}^{2}(\mathrm{sd}=2 . \mathrm{n}=371)=5,01 ; \mathrm{p}>0.05\right]$ based on professional seniority.

\subsection{Union Membership Variable}

Table 6 provides the test results conducted to identify the relationship between teachers' levels of organizational support and organizational identification and climate of initiative based on union membership variable.

Table 6 displays no significant differences on teacher views of union membership on organizational identification $(\mathrm{U}=5247,50 ; \mathrm{p}>0.05)$, climate of initiative $(U=5483,00 ; p>0.05), \quad$ total organizational support $(\mathrm{U}=4996,50 ; \mathrm{p}>0.05)$, and the sub dimensions of organizational support: administrative support $(\mathrm{U}=5158,00 ; \mathrm{p}>0.05)$, justice support $(\mathrm{U}=4931,50 ; \mathrm{p}>0.05)$ and instructional support $(\mathrm{U}=5070,50 ; \mathrm{p}>0.05)$ based on union membership. Lack of significant differences in this regard may mean that this variable does not affect teacher views.

\subsection{Relationship of Teacher Views on Climate of Initiative and Levels of Organizational Support and Organizational Identification}

Table 7 presents the data obtained from the correlation analysis conducted to determine whether there were significant differences between teachers' climate of initiative and levels of organizational support and organizational identification

Table 7 shows low level, positive and significant relationships between teachers' climate of initiative and their organizational support and organizational identification levels. Examination of the relationship of teacher views on climate of initiative and their views on organizational identification, organizational support and their sub dimensions presents the following findings: A low level, positive and significant relationship was found between teacher views on climate of initiative and their views on identification levels $(r=, 17 ; p=, 010)$. A low level, positive and significant relationship was detected between teachers' initiative levels and their organizational support levels $(\mathrm{r}=, 27$; $\mathrm{p}=, 000)$. No relationship was found for teachers' initiative levels and their instructional support levels $(r=, 01 \mathrm{p}=, 926)$. A low level, positive and significant relationship was found between teachers' climate of initiative and administrative support levels $(\mathrm{r}=, 29 ; \mathrm{p}=, 000)$. A low level, positive and significant relationship was found between teachers' climate of initiative and justice support levels $(r=, 28 ; \mathrm{p}=, 000)$.

\section{Discussion}

Findings of the current study which aimed to identify teacher views on organizational support, organizational 
identification and climate of initiative levels and to determine whether these views significantly differed based on demographic variables are presented in this section and discussed with the help of relevant literature.

According to research results, teachers "agreed" with organizational support level total scale and its instructional support and justice support sub dimensions and "partially" agreed with the administrative support dimension. The sub dimension with the highest means was found to be justice support and the sub dimension with the lowest means was found to be administrative support. Examination of relevant studies shows that also in Eğriboyun [30], Derinbay [27] and Nayır's [67] studies teachers agreed with organizational support level total scale. In these studies, they were undecided about their organizational identification levels. It is observed that teachers have low level identification with their schools. Relevant studies present the following findings: teachers' identification with their schools was found to be at medium level in Yıldız [106] and Akpınar's [3] studies, at normal level in Yetim's [105] study and at high level in Ekinci's [32] study where they agreed with the level of organizational identification.

Teachers were "undecided" in their climate of initiative levels. This finding may be interpreted in a manner that teachers display recessive behaviors in assessing the opportunities that may benefit their organizations, providing solutions when faced with problems, feeling responsible towards the organization and taking the initiative when required. Frese, Fay, Hilburger, Leng and Tag [40] and Frese and Fay [39] reported that teachers have normal levels of taking the initiative and feeling responsibility towards their organizations.

No significant differences were found in teachers' organizational identification, climate of initiative levels and in all sub dimensions of organizational support and in the total scale based on gender. However, it was observed that levels of male teachers were found to be higher than those of female teachers in organizational identification, climate of initiative levels and in all sub dimensions of organizational support and in the total scale. This finding may be interpreted that male teachers internalize their work environments more than their female counterparts do, embrace the achievements of the school more and spend more time with administrators by displaying a positive stance towards them. Relevant studies also show that teachers' views on level of organizational identification $[9 ; 18 ; 71 ; 105 ; 25 ; 32 ; 98 ; 72$; 46] do not differ based on gender, $[65 ; 3 ; 49 ; 56 ; 36]$ but there were significant differences in some studies in favor of male teachers. Studies on organizational support also show that according to teacher views, gender is not regarded as a variable that creates difference $[97 ; 30 ; 27 ; 67 ; 37 ; 65]$.

No significant differences were found in teachers' organizational identification, climate of initiative levels and in all sub dimensions of organizational support and in the total scale based on marital status. However, it was observed that organizational support of single teachers were higher than that of married teachers in sub dimensions of organizational support (instructional support, administrative support, justice support) and in the total scale and that organizational identification and climate of initiative levels of married teachers were higher than those of single teachers. This finding can be interpreted that married teachers can take up extra responsibilities in activities organized for the benefit of their organizations to ensure the success of their organizations whereas single teachers, without thinking of taking the initiative for the benefit of their organization, prefer individual activities outside it in their free times.

At organizational identification level, it can be argued that male teachers identify with their organizations, form positive ties with their organization and present voluntary behaviors in the activities organized on behalf of their organizations, On the other hand, single teachers have lower perceptions of identification compared to their married counterparts due to personal reasons such as being new in their jobs, having higher expectations and disliking the organization they work in. Relevant studies show that according to teacher views, teachers' organizational identification levels do not significantly differ based on marital status $[9 ; 18 ; 19 ; 32 ; 25]$ and Demirer [25] reported that organizational identification levels of single teachers were lower than those of married teachers.

In terms of organizational support that is in favor of single teachers, it can be argued that single teachers can highlight their individual characteristics, achieve more by getting the support of administrators in the organization and display more active behaviors. Relevant studies point out that single teachers perceive more organizational support compared to married teachers based on teacher views [83; 43; 37]; however Nayır [67] reports that married teachers perceive more organizational support compared to single teachers.

No significant differences were found in teacher views on climate of initiative levels and in all sub dimensions of organizational support and in the total scale based on level of education. Examination of the relevant studies show no significant differences between teacher views on organizational support levels and their organizational support perceptions based on level of education $[67 ; 41 ; 46]$. Literature has parallel results to this finding. However, there is a significant difference in favor of teachers with undergraduate degrees at organizational identification level. On the other hand, it is observed that in climate of initiative levels, in organizational support sub dimensions such as instructional support and administrative support and in the total scale it was found that teachers with postgraduate degrees had higher levels compared to teachers with undergraduate degrees. Compared to teachers with postgraduate degrees, teachers with undergraduate degrees were found to have higher levels in organizational identification levels and justice support dimension. This finding may be show that teachers with postgraduate degrees can spend time with their administrators, students and colleagues and take up initiatives and responsibilities outside 
their realm of duties to work for increasing the achievements of the school and exert efforts in line with organizational goals. According to Polat [78], teachers with higher levels of education may not identify with their organizations and have lower levels of identification with their schools since they have options to work elsewhere [78]. Relevant studies show that, according to teacher views, organizational identification levels decrease along with increased level of education [10; 18] and that teachers with undergraduate training identify with their organizations more. According to other studies, level of identification does not significantly differ based on level of education $[65 ; 3 ; 32 ; 25 ; 98 ; 71 ; 46]$.

No significant differences were found in teachers' organizational identification, climate of initiative levels and in all sub dimensions of organizational support and in the total scale based on professional seniority. It can be argued that teachers' climate of initiative levels are not affected from professional seniority. On the other hand, it was observed that teachers with higher seniority had higher levels in organizational identification level and in organizational support sub dimensions (instructional support, administrative support, justice support) and in the total scale and it was found that teachers with 0-10 year initiative has higher levels of climate of initiative compared to other teachers.

The finding that teachers with higher seniority had higher organizations identification levels may be related to the fact that individuals working in one profession for long years adopt their work environments and they possess feelings of doing their job better with experience. Also, since teachers with higher seniority will have higher employment scores, they will have the chance to work in any schools that they desire to work. This will result in making plans for the future without any anxieties by creating a positive effect on teachers. Relevant studies show similar results in organizational identification levels based on teacher views [3; $65 ; 71 ; 105 ; 98 ; 72]$. Other studies report that increases in professional seniority result in positive increases in identification $[19 ; 78 ; 25 ; 32 ; 18 ; 49 ; 8]$.

It can be argued that teachers' organizational support levels are not affected from professional seniority variable. Investigation of relevant studies points that according to teacher views, organizational support levels of organizations did not statistically differ based on professional seniority [ 30 ; $27 ; 50 ; 65]$.

No significant differences were found in teachers' organizational identification, climate of initiative levels and in all sub dimensions of organizational support and in the total scale based on union membership of teachers. Lack of a significant difference in this regard may point that this variable does not affect teacher views. However, individuals who are members of a union will tend to regard the decisions taken by the union as binding and act with the union members in the face of any problems at the organization or regarding any tasks in question. Individuals without membership to any unions will make personal decisions in these cases without being under the influence of anyone and can take personal initiatives. It can be argued that compared to teachers without union membership or with membership of some other union, teachers with a certain union membership, with the desire to come into prominence or attract attention, create a group inside the organization to look after the organization, to become aware of existing problems and to strive to meet the deficits caused by drawbacks in physical and equipment domains. Since teachers without any union membership will not have such concerns, they may have lower levels of identification with the school administration or the organization.

Since teachers with union membership will prefer to act by taking the support of the administration in the activities they will organize or in the conventions they will make against other unions, they will present a more intimate stance to the school administration and tend to increase the support received from the management.

In terms of the relationships between teachers' climate of initiative and levels of organizational support and identification; a low level and significant relationship was found was between teachers' climate of initiative and level of organizational identification and a negative relationship was detected between teachers' climate of initiative and instructional support which is a sub dimension of organizational support. On the other hand, a positive and low level significant relationship was found between teachers' climate of initiative total support, administrative support and justice support, which are sub dimensions of organizational support.

In this context, it can be argued that teachers can be said to take more initiatives in the organization and in matters related to organization while their organizational identification levels increase. When identification is strong, the individuals identify with their organizations and define them as they would define themselves [103]. If teachers are happy with the support they receive from their organizations and they are comfortable there, they will perform more tasks and contribute to their organizations more with the help of higher job performance [102]. However, the fact that the level is low shows us that teachers do not have suitable environments in their schools to take initiative. On the other hand, teachers lose the sense of belonging to their organizations when they do not receive the expected attention and support from their organizations but they will still want to transfer professional knowledge and skills to their students based on professional sense of duty and respect although they do not plan on taking the initiative for their organizations.

Valuing members in an organization will ensure that they will meet their expectations in not feeling lonely in good or bad days and feeling the support of their organizations and it will be effective in their forming ties of affection with their organizations [97]. Organizational support requires a special approach that will make the members of the organization feel safe and backed by their organization. Organizations that 
have this approach can create happier and more satisfactory work climates as a result of supporting their employees with tangible or intangible rewards for their contributions to the organization. These types of climates will ensure that employees are happier and more satisfied (Watkins, 1995, cited in: [2]). However, it is believed that when teachers' expectations are not met and when they feel they do not receive sufficient support from the organization, they will perform only the tasks that are legally binding and will not take the initiative in additional tasks for the benefit of their organizations. On the other hand, it is crucial for teachers to work in schools where they can better express themselves and where they can be of better use to their students so that successful training can be provided. Meeting teachers' needs, realizing their expectations and offering a positive psychological climate to teachers will ensure formation of a positive organizational climate. Teachers will strive to perform their tasks in the best possible manner in such positive climates [86]. School administrators have to be influential on teachers by preventing negative conditions that hinder teachers from doing their duties in order to realize organizational goals and to increase teachers' commitment to school [48]. Hence, school administrators should improve working conditions for teachers and be supportive; value teachers' views and ideas, take their complaints into consideration and attend to their problems one on one [73]. When teachers feel that the required conditions for increasing achievement are not met, such as providing the materials and equipment necessary for classes and promoting teachers' professional development, a negative climate will be generated in the organization. In this case, teachers will feel that the administrator is incompetent at physical, technical and school management levels and they will resist in team activities and will not want to take the initiative. However, teachers who love and care for their profession will take the initiative for their classes and their students under all circumstances.

Teachers expect school administrators to openly share the decisions made by them, to be consistent and to keep their promises. Hence, teachers prefer feeling psychologically comfortable in the organization and forming good relationships with their administrators. Literature cites that these good relationships will ensure that teachers will feel as a part of their organizations [75]. As long as school administrators display these behaviors, the employees feel they are supported and trust and commitment towards the leader and the organization will be generated [5]. School administrators are managers with positive characteristics who contribute to teachers' personal and professional growth, support teachers in all domains, have teachers use the education and training environment effectively and who display a collaborative attitude by having teachers participate in decision making [4]. However, teachers want to show their reaction by not taking the imitative while performing their duties due to inconsistent behavior of the administrators or when they have negative feelings for them. Individuals try to define whether they are subjected to fair treatment in the workplace and they act on this feeling of justice; it is expressed that employees' present positive attitudes towards the organization and the people in it when they feel that all employees are treated fairly [62]. On the other hand, teachers are very distant from their organizations and their administrators and do not think of taking the initiative in matters related to school due to lack of appreciation on the part of the administrators, unfair distribution of tasks and discrimination and favoritism in matters of class schedules and hall duty.

As a result, the fact that the expectations of the teachers who work successfully for the public personnel selection examination in the conditions of Turkey for many years and their expectations from their professions are very high despite the fact that they have not been able to meet these expectations, are also preventing their frustration from taking initiatives like decreasing their loyalty to their profession. In this case, teachers can prefer to carry out their daily professional activities instead of taking initiative. The fact that teachers receive post-graduate education after their undergraduate education period also raises the issue of taking similar initiatives. Teachers who cannot find what they expect in their organizations are struggling to go through other organizations by raising their education levels. In this case, teachers' incentive use levels that are not identified by the organizations they work for and who are not authorized and whose expectation levels are not met can also be decreased.

Suggestions developed in line with research results are provided below:

1. School administration should contribute to teachers to develop their professional skills, provide the conditions where teachers can make their own decisions and offer modern physical environments in which professional knowledge and skill can be implemented with the required materials and tools.

2. School administrators should direct their attitudes and tasks based on teacher behaviors and develop strategies that will guide the realization of teachers' personal goals and the goals of the organization and also specify the awards and punitive actions.

3. School administrators should plan socio-cultural activities that will cement synergy by emphasizing that the school is a unified entity with all teachers and staff and it is necessary to act together in order to achieve success

4. Arrangements should be made to ensure that teachers can pursue their academic goals and organizational support perceptions should be increased by acting with sensitivity and tolerance towards teachers' personal needs and emotions and by being fair to all teachers in all domains.

5. School administrators should listen to teachers' views and suggestions and create supportive behaviors and environments that will make teachers 
feel valued and appreciated and that will provide feedback.

6. It should be ensured that teachers with higher seniority guide teachers with less seniority and synergy between them should be increased to provide higher levels of identification.

7. Future studies should be conducted to investigate and pinpoint the factors that result in indecisions on the part of teachers in taking initiative

NOTE: This paper is based on the second author's master's thesis, which was directed by the first author.

\section{REFERENCES}

[1] Akalın, Ç. (2006). Duygusal Örgütsel Bağlılık Gelişimininde Çalışanların Algıladıkları Örgütsel Destek ve Ara Bir Değişken Olarak Örgüt Temelli Öz Saygı. Yayımlanmamış, Yüksek Lisans Tezi, Hacettepe Üniversitesi, Sosyal Bilimler Enstitüsü, Ankara.

[2] Akın, M. (2008). Örgütsel destek, sosyal destek ve iş/aile çatışmalarının yaşam tatmini üzerindeki etkileri. Erciyes Üniversitesi Sosyal Bilimler Enstitüsü Dergisi, 25, 141-170.

[3] Akpınar, A. (2014). Okullardaki İnsan İlişkileri Düzeyi İle Öğretmenlerin Örgütsel Özdeșleşme Düzeyleri Arasındaki İlişki. Yayımlanmamış Yüksek Lisans Tezi, Uşak Üniversitesi Sosyal Bilimler Enstitüsü, Uşak.

[4] Argon, T. (2014). Eğitim kurumlarında insan kaynaklarının desteklenmesi: Yönetici desteğine yönelik öğretmen görüşleri. International Journal of Human Sciences, 11(2), 691-729.

[5] Argyris, C. (1957). Personality and Organization: the Conflict between System and the Individual. New York: Harper. OCLC 243920

[6] Armeli, S. Eisenberger, P.F. \& Lynech, P. (1998). Perceived Organizational Support of Police Performance: The Moderating Influence of Sociemotional Needs. Journal of Applied Psychology, 83(2), 288-297.

[7] Aykan, E. (2007). Algılanan Örgütsel Destek İle Örgütsel Güven ve Tükenme Davranıșı Arasındaki İlișkilerin Belirlenmesine Yönelik Bir Araștırma. 15. Yönetim ve Organizasyon Bildirileri Kitab1, 159- 170, Sakarya Üniversitesi, Sakarya

[8] Barker, J. R. \& Tompkins, P. K. (1994). Identification in the Self-Managing Organization: Characteristics of Target and Tenure. Human Communication Research, 21(2), 223-240.

[9] Başar, U. (2011). Örgütsel adalet algısı, örgütsel özdeşleşme ve iş tatmini arasındaki ilişkilere yönelik görgül bir araştırma. Yayınlanmamış Yüksek Lisans Tezi, Kara Harp Okulu Savunma Bilimleri Enstitüsü, Ankara.

[10] Bhattacharya, C. B. Rao, H. \& Glynn, M. A. (1995) Understanding the bond of identification: An investigation of its correlates among art museum members. The Journal of Marketing, 59, 46-57.

[11] Binnewies, C., Ohly, S., \& Sonnentag, S. (2007). Taking personal initiative and communicating about ideas: What is important for the creative process and for idea creativity? European Journal of Work and Organizational Psychology, 16(4), 432-455.

[12] Can, A. (2013). SPSS ile bilimsel araştırma sürecinde nicel veri analizi. Ankara: Pegem Akademi.

[13] Crant, J. M. (2000). Proactive behavior in organizations. Journal of Management, 26(3), 435-462.

[14] Celep, C. Keleş, F. \& Konakl1, T. (2009). Öğretim elemanlarının adanmışlık ve örgütsel destek algıları. 18. Ulusal Eğitim Bilimleri Kurultay1, 369. Ege Üniversitesi Eğitim Fakültesi, İzmir.

[15] Ceylan, A. \& Șenyüz, P.B. (2003). Örgütsel Destek Algısı ve Dâhil Olma Dışlanmama Algısının Örgütsel Bağlılığa Etkisi Sigorta Sektöründe Bir Araştırma, Yönetim Dergisi, 14(44), $57-62$.

[16] Cole, M. S. \& Bruch, H. (2006). Organizational identity strength, identification, and commitment and their relationships to turnover intention: Does organizational hierarchy matter? Journal of Organizational Behavior, 27(5), $585-605$

[17] Çakar, N. D. \& Yıldız, S. (2009). Örgütsel adaletin iş tatmini üzerindeki etkisi: algılanan örgütsel destek bir ara değişken mi? Elektronik Sosyal Bilimler Dergisi, 8(28), 68-90.

[18] Çakınberk, A., Derin, N. \& Demirel, E. (2011). Örgütsel özdeşleşmenin örgütsel bağlılıkla biçimlenmesi: Malatya ve Tunceli özel eğitim kurumları örneği. Işsletme Araştırmaları Dergisi, 3(1), 89-121.

[19] Çelik, A. \& Findık, M. (2012). The Effect of Perceived Organizational Support on Organizational Identification. World Academy of Science, Engineering and Technology, 68, $8-29$.

[20] Çırakoğlu, H. (2010). Örgütsel Özdeşleșme ve İş Doyumu İlişkisi. Yayınlanmamış Yüksek Lisans Tezi, Dokuz Eylül Üniversitesi Sosyal Bilimler Enstitüsü, İzmir

[21] Çorbacıŏglu, S. (2012). Algılanan örgütsel desteğin örgütsel bağlılığa etkisi, imalat sektöründe faaliyet gösteren bir işletme örneği. Gazi Üniversitesi İktisadi ve İdari Bilimler Fakültesi Dergisi, 14(1), 29-52.

[22] Demir, M. (2012). Örgütsel destek, örgütsel bağll1ık ve ișten ayrılma eğilimi ilişkisi: havalimanı yer hizmetleri ișletmelerine yönelik bir araștırma. İs Güç Endüstri İlișkileri ve İnsan Kaynakları Dergisi, 14 (1), 47-64.

[23] Demircan, C.N. \& Yıldız, S. (2009). Örgütsel Adaletin İş Tatmini Üzerindeki Etkisi. Elektronik Sosyal Bilimler Dergisi, 8(28), 68-90.

[24] Demirci, Ü. (2010). Örgütsel Özdeşleşme ve Örgütsel Güvenin Çalışan Performansı Üzerindeki Etkisi. Yayımlanmamış Yüksek Lisans Tezi, İstanbul Üniversitesi Sosyal Bilimler Enstitüsü, İstanbul.

[25] Demirer, S. (2014). Öğretmenlerin örgütsel sosyalleșme ve özdeşleşme düzeyleri ile birlikte çalışma yeterlikleri arasındaki ilişki. Yayımlanmamış Yüksek Lisans Tezi, Abant İzzet Baysal Üniversitesi Eğitim Bilimleri Enstitüsü.

[26] Demirtaş, H. \& Güneş, H. (2002). Eğitim yönetimi ve denetimi sözlüğü. Ankara: Anı Yayınc1lık. 
[27] Derinbay, D. (2011). İlköğretim okullarında görev yapan ögretmenlerin algıladıkları örgütsel destek düzeyleri. Yayımlanmamış Yüksek Lisans Tezi, Denizli: Pamukkkale Üniversitesi Sosyal Bilimler Enstitüsü, Bolu.

[28] Dirin, İ, (2014). Alg1lanan Örgütsel Desteğin Örgütsel Özdeşleşme Üzerindeki Etkisi: TRB-2 Bölgesinde Uygulamalı Bir Araştırma. Yayımlanmamış Yüksek Lisans Tezi, Isparta.

[29] Dutton, J., Dukerich, J. \& Harquail, C.V. (1994). Organizational images and membership commitment. Administrative Science Quarterly, 39(2), 239-263.

[30] Eğriboyun, D. (2013). Ortaögretim Okullarında Görev Yapan Yönetici ve Ögretmenlerin Örgütsel Güven, Örgütsel Destek ve Örgütsel Bă̆lllıkları Arasındaki İlişki. Yayımlanmamış Yüksek Lisans Tezi, Abant İzzet Baysal Üniversitesi Eğitim Bilimleri Enstitüsü, Bolu.

[31] Eisenberger, R., Huntington, R., Hutchison S. \& Sowa, D. (1986). Perceived Organizational Support. Journal of Applied Psychology, 71(3), 500-507.

[32] Ekinci, S. (2015). Illk ve ortaokul ögrretmenlerinin örgütsel özdeşleşme ve örgütsel sinizm düzeylerine ilişkin görüşleri. Yayımlanmamış Yüksek Lisans Tezi, Abant İzzet Baysal Üniversitesi Eğitim Bilimleri Enstitüsü, Bolu.

[33] Erdoğdu, M. Y \& Aydındağ, Z. (2013). Öğretmenlerin kurumsal özdeşleşme ve bağlılıklarının algılanan yönetici davranıșları açısından incelenmesi. İstanbul Sabahattin Zaim Üniversitesi Sosyal Bilimler Enstitüsü Dergisi, 1 (2),158-173.

[34] Ertürk, A. (2003). Örgütsel Kimlik Algısı: Etkileyen Faktörler ve Sonuçları. Yayımlanmamış Doktora Tezi, Gebze İleri Teknoloji Enstitüsü, Gebze.

[35] Eser, G. (2011). Güven eğiliminin örgütsel destek üzerindeki etkisi. Marmara Üniversitesi İ̈BF Dergisi, 30 (54), 365-376.

[36] Fındık, M. (2011). Algılanan Örgütsel Desteğin, Örgütsel Özdeşleşme ve İşten Ayrılma Niyetine Etkisi Araştırması: Konya Aile Hekimleri Örneği. Yayımlanmamış Doktora Tezi, Selçuk Üniversitesi Sosyal Bilimler Enstitüsü, Konya.

[37] Foley, S. Hang-Yue, N. \& Lui, S. (2005). The effects of work stressors, perceived organizational support, and gender on work-family conflict in Hong Kong. Asia Pacific Journal of Management, 22(3), 237-256.

[38] Frese, M. Kring, W. Soose, A. \& Zempel, J. (1996). Personal initiative at work: Differences between East and West Germany. Academy of Management Journal, 39, 37-63.

[39] Frese, M. \& Fay, D. (2001). Personal initiative (P1): A concept for work in the 21 st century. Research in Organizational behavior, 23, 133-188.

[40] Frese, M., Fay, D., Hilburger, T., Leng, K. \& Tag, A. (1997). The conception of personal initiative: Operationalization, reliability and validity in two German samples. Journal of Occupational and Organizational Psychology, 70, 139-161.

[41] Fuller, B. J., Hester, K., Barnett, T., Frey, L. \& Relyea, C. (2006). Perceived organizational support and perceived external prestige: predicting organizational attachment for university faculty, staff and administration.

[42] Güney, S., Akalın, C. \& İlsev, A. (2007). Duygusal örgütsel bağlılık gelişiminde algılanan örgütsel destek ve örgüt temelli öz-sayg1. Hacettepe Üniversitesi İktisadi ve İdari Bilimler Fakültesi Dergisi, 25(2), 189-211.

[43] Güner, A. R. (2007). Sağlık Hizmetlerinde Örgütsel Bağlllık, Isşe Bağlllık ve Iș Tatmini Arasındaki İlişkilerin Modellenmesi. Yayımlanmamış Yüksek Lisans Tezi, Akdeniz Üniversitesi Sosyal Bilimler Enstitüsü, Antalya.

[44] Gürbüz, R. (2012). Alg1lanan Örgütsel Destek Ve Örgütsel Güvenin, Örgütsel Bağl1lık İle İlişkisi. Yayımlanmamış Yüksek Lisans Tezi, Atatürk Üniversitesi Sosyal Bilimler Enstitüsü, Erzurum.

[45] Hartog, D. N. Den \& Belschak F. D. (2007). Personal initiative, commitment and affect at work. Journal of Occupational and Organizational Psychology, 80, 601-622.

[46] Hatipoğlu, Z. (2015). Öğretmenlerin Örgütsel Destek AlgllarınınÖrgütsel Özdeşleşme Seviyelerine Etkisi: Ankara Çankaya İlçesinde Bir Uygulama. Yayımlanmamıș Yüksek lisans Tezi, Çankaya Üniversitesi Sosyal Bilimler, Ankara.

[47] Işık, E. (2014). Rol Belirsizliği, Rol Çatışması, Örgütsel Destek ve Sağlı Çalışanlarında Tükenmişlik. Yayımlanmamış Yüksek Lisans Tezi, Beykent Üniversitesi Sosyal Bilimler Enstitüsü, İstanbul.

[48] İnceler, S. (2005). İlköğretim okulu yöneticilerinin ögretmenlerin mesleki gelişimlerine yönelik öğretimsel liderlik davranışları. Yayımlanmamış Yüksek Lisans Tezi, Bolu: Abant İzzet Baysal Üniversitesi Sosyal Bilimler Enstitüsü.

[49] İşcan, Ö.F. (2006). Dönüştürücü/ etkileşimci liderlik alg1S1 ve örgütsel özdeşleşme ilişkisinde bireysel farklılıkların rolü. Akdeniz Üniversitesi İdari ve İktisadi Bilimler Fakültesi Dergisi, 11,160-177.

[50] Kalağan, G. (2009). Araştırma Görevlilerinin Örgütsel Destek Alglları ile Örgütsel Sinizm Tutumları Arasındaki İlişki. Yayımlanmamış Yüksek Lisans Tezi, Akdeniz Üniversitesi Sosyal Bilimler Enstitüsü, Antalya.

[51] Kaplan, M. \& Öğüt A. (2012). Algılanan örgütsel destek ile örgütsel bağl1lı arasındaki ilişkinin analizi: Otel işletmelerinde bir uygulama. Süleyman Demirel Üniversitesi İktisadi ve İdari Bilimler Fakültesi Dergisi, 17(1), 387-401.

[52] Karabey, C.N. (2005). Örgütsel özdeşleşme, örgütsel imaj ve örgütsel vatandaşlık davranışı ilişkisi. Yayımlanmamış Yüksek Lisans Tezi, Atatürk Üniversitesi Sosyal Bilimler Enstitüsü, Erzurum.

[53] Karabey, C.N. \& İșcan, Ö.F. (2007). Örgütsel özdeşleşme, örgütsel imaj ve örgütsel vatandaşlık davranıșı arasındaki ilişki: Bir uygulama. Atatürk Üniversitesi İktisadi ve İdari Bilimler Dergisi, 21(2), 231-241.

[54] Karakurt A, (2012). Öğretmenlerin İș Yerinde Yalnızlık Düzeyinin Örgütsel Destek Ve Bazı Değişkenler Açısından İncelenmesi. Yayımlanmamış Yüksek Lisans Tezi Necmeddin Erbakan Üniversitesi Eğitim Bilimleri Enstitüsü, Konya

[55] Karasar, N. (2005). Bilimsel Araştırma Yöntemi. Ankara: Nobel Yayın Dağıtım.

[56] Korkut, H. (1988). Üniversitelerde akademik olmayan personelin iş doyumu ve örgütle özdeşleşmesi. Ankara: Bilkent Üniversitesi.

[57] Köse, S. \& Gönüllüoğlu S. (2010). Örgütsel desteğin örgütsel 
bağlllık üzerindeki etkisini belirlemeye yönelik bir araștırma. Dumlupınar Üniversitesi Sosyal Bilimler Dergisi, 27. http://dergipark.ulakbim.gov.tr/dpusbd/article/view/50001264 $46 / 5000116244$

[58] Krejcie, R. V. \& Morgan, D. W. (1970). Determining sample size for research activities. Educational Psychological Measurement.30, 607-610.

[59] Kurt, T, Duyar İ, \& Yakut, B. (2015). Ögrretmenlerin Örgütsel Destek ve Psikolojik Güven Algiss ile Insiyatif Almalar Arasındaki Illişkiler. 10. Ulusal Eğitim Yönetimi Kongresi Bildiri Özetleri (7-9 Mayıs). Ankara: Pegem Yayıncılık, $359-360$

[60] Loga, A. (2003). Çalıșanların demografik özelliklerinin örgütsel özdeşim, örgütsel bağlılık ve örgütsel vatandaşlı davranıșina etkileri: Askeri birimlerde bir araștırma. Yayımlanmamış Yüksek Lisans Tezi. Ankara: Başkent Üniversitesi Sosyal Bilimler Enstitüsü.

[61] Miller, V. D. Allen, M., Casey, M. K. \& Johnson, J. R. (2000). Reconsidering the organizational identification questionnaire. Management Communication Quarterly, 13(4), 626-658.

[62] Moorman, R. H. (1991). Relationship between organizational justice and organizational citizenship behaviors: Do fairness perceptions influence employee citizenship? Journal of Applied Psychology, 76(6), 845

[63] Morrison, E. W., \& Phelps, C. C. (1999). Taking charge at work: Extra role efforts to initiate workplace change. Academy of Management Journal, 42(4), 403-419.

[64] Mustafayeva, L. (2007). Sosyal sorumluluk ile örgütsel vatandaşlık davranışları ve örgütsel özdeşleșme arasındaki ilişkiye yönelik bir araştırma. Yayımlanmamış Yüksek Lisans Tezi, Dumlupınar Üniversitesi Sosyal Bilimler Enstitüsü, Kütahya.

[65] Nartgün, Ş.S. \& Kalay, M. (2014), öğretmenlerin örgütsel destek, örgütsel özdeşleşme ile örgütsel sinizm düzeylerine ilişkin görüşleri. Turkish Studies Dergisi, 9(2), 1361-1376.

[66] Natunann, S. E., Bies, R. J. \& Martin,C. L. (1995). The roles of organizational support and justice during a layoff. Academy of Management Journal,1, 89-93.

[67] Nayır, F. (2011). İlköğretim Okulu Yöneticilerinin Öğretmenlere Sağlanan Örgütsel Desteğe İlişkin Görüsleri, Ögretmenlerin Örgütsel Destek Alglsı ve Örgütsel Bağlılıkla Illiskisi. Yayımlanmamıs Doktora Tezi. Ankara Üniversitesi Eğitim Bilimleri Enstitüsü, Ankara

[68] Ohly, S., Sonnentag, S. \& Pluntke, F. (2006). Routinization, work characteristics, and their relationships with creative and proactive behaviors. Journal of Organizational Behavior, $27,257-279$

[69] Oktar M. N, (2015). Engelli Bireylerle Çalışanlarda Algılanan Örgütsel Destek Ve Tükenmisslik Düzeyinin İs Tatmini Üzerindeki Etkisi: İstanbul İli Beykoz İlçesi Örneği. Yayımlanmamıs Yüksek Lisans Tezi, Yalova Üniversitesi, Sosyal Bilimler Üniversitesi, Yalova.

[70] Özbek, M. F. \& Kosa, G. (2009). Duygusal bağl1l1k, örgütsel destek, üst yönetim desteği ve personel güçlendirmenin hizmet kalitesi üzerindeki etkisi: Kırgızistan'da banka işgörenleri üzerinde bir uygulama. Erciyes Üniversitesi İktisadi ve İdari Bilimler Fakültesi Dergisi, 34, Temmuz-Aralık, 189-212.
[71] Özdemir, A. (2010). Örgütsel özdeşleşmenin algılanan örgütsel destek, cinsiyet ve k1dem değişkenlerine göre incelenmesi. Türkiye Sosyal Araștırmalar Dergisi, 14(1), 237250 .

[72] Özdemir, H.Ö. (2007). Çalışanların Kurumsal Sosyal Sorumluluk Algllamalarının Örgütsel Özdeşleşme, Örgütsel Bağlllık Ve İș Tatminine Etkisi: OPET Çalıșanlarına Yönelik Uygulama. Yayımlanmamış Doktora Tezi, Marmara Üniversitesi Sosyal Bilimler Enstitüsü, İstanbul.

[73] Özdevecioğlu, M. (2003). Alg1lanan örgütsel destek ile örgütsel bağlllık arasındaki ilişkilerin belirlenmesine yönelik bir araștırma. Dokuz Eylül Üniversitesi İktisadi ve İdari Bilimler Fakültesi Dergisi, 2(18), 113-130.

[74] Özdevecioğlu, M. (2004). Algılanan örgütsel desteğin işten ayrılma niyeti üzerindeki etkileri. Amme İdaresi Dergisi, 37 (4), 97-115.

[75] Özgan, H., Kalman, M. \& Bozbayındır, F. (2012). Okul sağlı̆̆l açısından okul yöneticisinin hesap verilebilirliği, ögretmenlerin iş doyumu ve örgütsel adalet arasındaki iliskinin incelenmesi. 21. Ulusal Eğitim Bilimleri Kongresi Bildiri Özetleri (12-14 Eylül). Ankara: Pegem Yayıncılık, 170.

[76] Özsöylemez, O. (2009). Algılanan Liderlik Tarzlarının İș Tatmini Ve İşten Ayrılma Niyeti Üzerindeki Etkisinde Örgütle Özdeşleşmenin Rolü. Yayınlanmamıs Yüksek Lisans Tezi, İstanbul: Marmara Üniversitesi Sosyal Bilimler Enstitüsü.

[77] Parasuraman, S., Greenhaus, J. H. \& Granrose, C. S. (1992). Role stressors, social support, and well-being among twocareer couples. Journal of Organizational behavior, 13(4), 339-356.

[78] Polat, M. (2009). Örgütsel Özdeşleşmenin Öncülleri ve Ardılları Üzerine Bir Saha Çalışması. Yayınlanmamıș Doktora Tezi, Uludağ Üniversitesi Sosyal Bilimler Enstitüsü, Bursa.

[79] Rhoades, L., Eisenberger, R., \& Armeli, S. (2001). Affective commitment to the organization: the contribution of perceived organizational support. Journal of Applied Psychology, 86(5), 825-836.Doi.10.1037//0021-9010.86.5.825

[80] Rhoades, L. \& Eisenberger, R. (2002). Perceived organizational support: a review of the literature. Journal of Applied Psychology, 87(4), 698-714. Doi 10.1037/0021-9010.87.4.698

[81] Rousseau, D. M. (1998). Why workers still identify with organizations. Journal of Organizational Behavior, (19), 217-233.

[82] Selçuk, G. (2003). Örgütsel Desteğin Çalışanların İş İle İlgili Tutumlarına Etkisi. Yayımlanmamış Yüksek Lisans Tezi, Dokuz Eylül Üniversitesi Sosyal Bilimler Enstitüsü, İzmir

[83] Shaffer, M. A \& Harrison, D. A. (2001). Forgotten partners of international assignments: development and test of a model of spouse adjustment. Journal of Applied Psychology, 86(2), 238.

[84] Shalley, C.E, Gilson, L.L. \& Blum, T.C.(2000). Matching creativity requirements and the work environment: Effects on satisfaction and intentions to leave. Academy of Management Journal, 43(2), 215-223.

[85] Shore, L. M. \& Wayne, S.J. (1993). Commitment and employee behavior: comparison of affective commitment and 
continuance commitment with perceived organizational support. Journal of Applied Psychology, 78 (5), 774- 780.

[86] Silah, M. (2001). Eğitim örgütlerinde hizmetin niteliğini arttırmak için personelin ödüllendirilmesi. Cumhuriyet Üniversitesi İktisadi ve İdari Bilimler Dergisi, 2(1), 95-109.

[87] Solmaz, H. (2010). Örgütsel Özdeşleşmenin İşten Ayrılma Niyetine Etkisinde Örgütsel Adaletin Aracılık Rolü. Yayınlanmamış Yüksek Lisans Tezi, Ufuk Üniversitesi Sosyal Bilimler Enstitüsü, Ankara.

[88] Sonnentag, S. (2003). Recovery, work engagement, and proactive behavior: A new look at the interface between non-work and work. Journal of Applied Psychology, 88(3), 518-528. Doi 10.1037/0021-9010.88.3.518.

[89] Spier, E. ve Stroppa, C. (2010). The role of social support and personal initiative. International Journal of Intercultural Relations, 35, 234-245.

[90] Suliman, A. M. T. (2001). Work performance: Is it one thing or many things? The multidimensionality of performance in a Middle Eastern context. The International Journal of Human Resource Management, 12(6), 1049-1061. Doi $10.1080 / 713769689$

[91] Şimşek, M.Ş., Akgemici, T. \& Kaplan, M., (2008). Algılanan Örgütsel Destek ve Örgütsel Güven ile Tükenme Davranışı Arasındaki ilişkilerin Analizi: Nevşehir Üniversitesi Akademik Personel Örneği. 16.Yönetim ve Organizasyon Kongresi Bildiriler Kitabı, İstanbul Kültür Üniversitesi, Antalya, 445-452.

[92] Şişman, M. (2000). Öğretmenlik mesleğine giriş. 2. Baskı, Ankara: Pegem, A Yayıncılık.

[93] Tak, B. \& Çiftçioğlu, A. (2009). Algılanan örgütsel prestij ile örgütsel bağlılık ve örgütsel özdeşleşme arasındaki ilişkilerin incelenmesine yönelik bir araştırma. Akdeniz Üniversitesi İ.İ.B.F. Dergisi, 18, 100-116.

[94] Tokgöz, E. (2012). Örgütsel Güven, Örgütsel Özdeşleşme Ve Örgütsel Vatandaşlık Davranışı Arasındaki İlişki. Yayımlanmamış Yüksek Lisans Tezi, Balıkesir Üniversitesi Sosyal Bilimler Enstitüsü, Balıkesir.

[95] Tompkins, P. K. \& Cheney, G. (1985). Communication and unobtrusive control in contemporary organizations. Organizational communication: Traditional themes and new directions, 13, 179-210.

[96] Turunç, Ö. (2010). Organizasyonlarda kontrol algılamalarının örgütsel özdeşleşme ve iş performansına etkisi. Cumhuriyet Üniversitesi İktisadi ve İdari Bilimler Fakültesi Dergisi, 11 (1), 251-269.

[97] Turunç, Ö. \& Çelik, M. (2010). Çalışanların algıladıkları örgütsel destek ve iş stresinin örgütsel özdeşleşme ve iş performansına etkisi. Yönetim ve Ekonomi, 17(2), 183
[98] Tüzün, İ. K. (2006). Örgütsel Güven, Örgütsel Kimlik ve Örgütsel Özdeşleşme İlişkisi, Uygulamalı Bir Çalışma. Yayımlanmamış Doktora Tezi, Gazi Üniversitesi, Sosyal Bilimler Enstitüsü, Ankara.

[99] Uçar, D. (2009). Perceived Organizational Support and Organizational Commitment: The Mediating Role of Organization-Based Self-Esteem. Master Dissertation, Yeditepe University Institute of Social Sciences, İstanbul.

[100] Uçar, D. \& Ötken B. (2010). Algılanan örgütsel destek ve şirkete bağlılık: Örgüt temelli öz-saygının rolü. Dokuz Eylül Üniversitesi İktisadi ve İdari Bilimler Fakültesi Dergisi, 25 (2), 85-105.

[101] Uray, M, (2014). Müşteri Odaklılık ve Örgütsel Güven İlişkisinde Örgütsel Özdeşleşme ve Örgütsel Bağlılığın Aracılık Rolü ve Bir Araștırma. Yayımlanmamıs Doktora Tezi, Marmara Üniversitesi Sosyal Bilimler Enstitüsü, İstanbul.

[102] Van Dick, R. \& Wagner, U. (2002). Social identification among school teachers: Dimensions, foci, and correlates. European Journal of Work and Organizational Psychology, 11 (2), 129-149.

[103] Wan-Huggins, V. N., Riordan, C. M. \& Griffeth, R. W. (1998). The development and longitudinal test of a model of organizational identification. Journal of Applied Social Psychology, 28(8), 724-749.

[104] Warr ve Fay D (2001). Age and personal initiative at work. European Journal of Work and Organizational Psychology, 10(3), 343-353.

[105] Yetim, A. E. E. (2010). Genel Liselerde Örgütsel İletişim ile Öğretmenlerin Örgütsel Özdeşleşmeleri Arasındaki İlişki. Yayımlanmamış Yüksek Lisans Tezi, Gazi Üniversitesi Eğitim Bilimleri Enstitüsü, Ankara.

[106] Yıldız, K. (2013). Öğretmenlerin örgütsel özdeşleşmeleri ile örgütsel iletişimleri arasındaki ilişkinin incelenmesi. Kuram ve Uygulamada Eğitim Bilimleri Dergisi, 13(1), 251-272.

[107] Yıldız, S. (2008). Örgüt Kültürünün İșten Ayrılma Eğilimi ve Çalışa n Verimliliği Üzerindeki Etkisi: Bir Ara Değişken Olarak Örgütsel Destek Algısı. Yayımlanmamış Yüksek Lisans Tezi, Abant İzzet Baysal Üniversitesi Sosyal Bilimler Enstitüsü, Bolu

[108] Y1lmaz, C. (2014). Örgütsel Güven ile Tükenmişlik Arasındaki İlişkide Algılanan Örgütsel Özdeşleşmenin Aracılık Etkisi: Uygulamalı Bir Çalışma. Yayımlanmamış Yüksek Lisans Tezi, Hacı Bektaş Veli Üniversitesi Sosyal Bilimler Enstitüsü, Nevşehir.

[109] Yokuş, İ. (2006). Erkek Egemen İşlerde Çalışanların Örgütsel Destek Alglları ve Örgütsel Bağlllıkları Arasındaki Illişki. Yayımlanmamış Yüksek Lisans Tezi, Hacettepe Üniversitesi Sosyal Bilimler Enstitüsü, Ankara. 